\title{
Further Studies on the Effects of 5-hydroxytryptophan on Plasma Glucose and Insulin in the Mouse
}

\author{
B. L. Furman and G. Ann Wilson \\ Department of Physiology and Pharmacology, University of Strathclyde, Glasgow, Scotland
}

Summary. The effects of 5-hydroxytryptophan on plasma concentrations of glucose and immunoreactive insulin were examined in conscious mice. Blood samples were obtained after anaesthetizing the mice lightly with ether at the desired time. Large doses of L-5-hydroxytryptophan (5HTP) $(200-400 \mathrm{mg} / \mathrm{kg}$ IV) produced a dose-dependent hypoglycaemic response in fasted mice (e. g. control $5.7 \pm$ $0.2 \mathrm{mmol} / \mathrm{l}, 5 \mathrm{HTP} 400 \mathrm{mg} / \mathrm{kg} 2.6 \pm 0.3 \mathrm{mmol} / \mathrm{l}$ ). This response was preceded by a significant elevation in the plasma immunoreactive insulin concentration (e. g. control $6 \pm 2 \mathrm{mU} / \mathrm{l} ; 5 \mathrm{HTP} 400 \mathrm{mg} / \mathrm{kg} 53 \pm$ $7 \mathrm{mU} / \mathrm{l})$. Induction of diabetes with alloxan $(80 \mathrm{mg} /$ $\mathrm{kg}$ IV $72 \mathrm{~h}$ previously) prevented the hypoglycaemic effect of 5HTP. Alloxan diabetes abolished the hyperinsulinaemic response to $100 \mathrm{mg} / \mathrm{kg}$ of $5 \mathrm{HTP}$ and reduced by $66 \%$ the response to $400 \mathrm{mg} / \mathrm{kg}$ of 5HTP. In alloxan diabetic mice 5HTP produced a marked hyperglycaemic response (control $17.9 \pm$ $2.0 \mathrm{mmol} / \mathrm{l} ; 5 \mathrm{HTP} 100 \mathrm{mg} / \mathrm{kg} 36.1 \pm 2.3 \mathrm{mmol} / \mathrm{l})$. In normal mice pre-treated with nialamide, a monoamine oxidase inhibitor, much lower doses of 5 HTP $(5-10 \mathrm{mg} / \mathrm{kg})$ were required to produce hypoglycaemia. There was no detectable elevation in the plasma insulin concentration accompanying the hypoglycaemic response to smaller doses of 5HTP in nialamide treated mice. The hyperinsulinaemic and hypoglycaemic actions of 5HTP in normal mice were prevented completely by pretreatment with benserazide, an inhibitor of aromatic amino acid decarboxylase. 5-hydroxytryptamine did not modify the plasma glucose concentration in either normal or nialamide-treated animals. It is concluded that the hypoglycaemic response to 5HTP in normal mice is mediated at least partly through an elevation in the plasma insulin concentration, although it is likely that additional mechanisms are involved.
Key words: 5-hydroxytryptophan, 5-hydroxytryptamine, plasma glucose, plasma insulin, nialamide, benserazide, diabetes in mice, alloxan diabetes.

5-hydroxytryptamine (5HT) has been demonstrated in the pancreatic B cells of several species [1] and these cells possess mechanisms which can take up and decarboxylate the 5HT precursor, 5-hydroxytryptophan (5HTP) [8]. This has led to considerable interest in the effect of $5 \mathrm{HT}$ and its precursors on blood glucose and insulin secretion. 5HT itself has been shown to produce hyperglycaemia $[12,15]$ although Kobayashi et al. [10] demonstrated a hypoglycaemic response to $5 \mathrm{HT}$, this being particularly pronounced in adrenal-demedullated rats. On the other hand precursors of 5HT (tryptophan and 5HTP) have been shown by several authors to produce hypoglycaemia in the rat or mouse $[4,12,13$, 15]. The mechanisms involved in these hypoglycaemic responses are unclear and there is uncertainty about the role of insulin. Lundquist et al. [12] and Furman [4] found no increase in the plasma immunoreactive insulin (IRI) concentration after the administration of 5HTP to mice pretreated with monoamine oxidase inhibitors and also found that the hypoglycaemic response to 5HTP could be obtained in alloxan diabetic animals. Smith and Pogson [15] on the other hand, failed to demonstrate a hypoglycaemic response to tryptophan in either alloxan or streptozotocin-diabetic rats or to $5 \mathrm{HTP}$ in pargylinetreated alloxan-diabetic rats or mice. These authors also demonstràted a very small but significant increase in the plasma immunoreactive insulin concentration after tryptophan injection but suggested that the increase was too small to account for 
Table 1. Effect of L-5-hydroxytryptophan (5HTP) on the plasma concentrations of glucose and immunoreactive insulin (IRI) at various times after intravenous injection in normal mice and in mice made diabetic by the IV injection of alloxan $(80 \mathrm{mg} / \mathrm{kg}, 72 \mathrm{~h}$ previously). Each value represents the mean \pm SEM of $6-14$ observations in the case of the control and the 200 and $400 \mathrm{mg} / \mathrm{kg}$ doses of $5 \mathrm{HTP}$, and of 5-8 observations in the case of the 50 and $100 \mathrm{mg}$ / $\mathrm{kg}$ doses

\begin{tabular}{|c|c|c|c|c|c|}
\hline \multirow[t]{2}{*}{ Treatment } & \multicolumn{3}{|c|}{ Plasma glucose, $\mathrm{mmol} / \mathrm{l}$} & \multicolumn{2}{|c|}{ Plasma IRI, mU/I } \\
\hline & $5 \mathrm{~min}$ & $30 \mathrm{~min}$ & $60 \min$ & $5 \min$ & $30 \mathrm{~min}$ \\
\hline \multicolumn{6}{|c|}{ Normal Mice } \\
\hline Control & $6.3 \pm 0.3$ & $6.9 \pm 0.6$ & $5.7 \pm 0.2$ & $6 \pm 2$ & $7 \pm 2$ \\
\hline $\begin{array}{l}5 \mathrm{HTP}, \\
50 \mathrm{mg} / \mathrm{kg}\end{array}$ & $5.8 \pm 0.3$ & $6.9 \pm 0.2$ & $5.1 \pm 0.2$ & $33 \pm 6^{b}$ & $26 \pm 3^{a}$ \\
\hline $\begin{array}{l}5 \mathrm{HTP}, \\
100 \mathrm{mg} / \mathrm{kg}\end{array}$ & $6.3 \pm 0.3$ & $6.6 \pm 0.3$ & $4.6 \pm 0.4$ & $51 \pm 13^{\mathrm{b}}$ & $40 \pm 8^{b}$ \\
\hline $\begin{array}{l}5 \mathrm{HTP}, \\
200 \mathrm{mg} / \mathrm{kg} \\
5 \mathrm{HTP}\end{array}$ & $4.7 \pm 0.3^{\mathrm{a}}$ & $4.9 \pm 0.4^{b}$ & $3.4 \pm 0.4$ & $55 \pm 9^{b}$ & - \\
\hline $400 \mathrm{mg} / \mathrm{kg}$ & $5.1 \pm 0.5$ & $3.1 \pm 0.7^{b}$ & $2.6 \pm 0.3$ & $53 \pm 7^{b}$ & - \\
\hline
\end{tabular}

\section{Alloxan diabetic mice}

\begin{tabular}{|c|c|c|c|}
\hline Control & - & $17.9 \pm 2.0-$ & $7 \pm 2$ \\
\hline $\begin{array}{l}5 \mathrm{HTP}, \\
100 \mathrm{mg} / \mathrm{kg}\end{array}$ & - & $36.1 \pm 2.3^{b}-$ & $9 \pm 3$ \\
\hline $\begin{array}{l}5 \mathrm{HTP}, \\
400 \mathrm{mg} / \mathrm{kg}\end{array}$ & - & $27.5 \pm 1.7^{b}-$ & $17 \pm 6^{a}$ \\
\hline
\end{tabular}

$a, b, c$ Indicates that the value is significantly different from the appropriate control value ( $\left.{ }^{\mathrm{a}} \mathrm{P}<0.05,{ }^{\mathrm{b}} \mathrm{P}<0.01,{ }^{\mathrm{c}} \mathrm{P}<0.001\right)$

the hypoglycaemic action. The work presented in this paper consists of a more detailed examination of the role of insulin in the hypoglycaemic response to 5 HTP in the mouse.

\section{Materials and Methods}

\section{Animals}

Male albino CFLP mice $(22-28 \mathrm{~g})$ were used throughout. The animals were maintained on a standard pellet diet (Oxoid 41B) and water ad libidum until $18 \mathrm{~h}$ before the experiment, at which time food, but not water, was removed.

\section{Experimental Procedures}

Drugs were administered to conscious mice intravenously into a tail vein or intraperitoneally as indicated. Blood sampling was achieved by anaesthetizing the animals lightly with ether approximately $30 \mathrm{~s}$ before the desired time and removing blood from the rapidly exposed femoral vein using a $26 \mathrm{~g}$ needle attached to a $1 \mathrm{mI}$ syringe. This method of blood sampling yields plasma glucose concentrations not significantly different from those obtained when blood is collected by decapitation, and is the preferred method in our laboratory. One blood sample only was removed from each mouse and thus different groups of animals were required for each time interval studied.

\section{Induction of Diabetes}

Diabetes was induced by the IV injection of alloxan $(80 \mathrm{mg} / \mathrm{kg}$ dissolved freshly in saline) $72 \mathrm{~h}$ before the experiment. These animals showed glycosuria (Clinistix) and had a mean fasting plasma glucose concentration of $17.9 \mathrm{mmol} / \mathrm{l}$.

\section{Experimental Design and Protocols}

Drug and control experiments were performed in a strictly parallel manner, drug or control solutions being administered to alternate mice selected at random. Where an experiment involved more than two treatments, the treatments were randomized over the whole time period of the experiment. All experiments were carried out between 1000 and $1300 \mathrm{~h}$. Where the numbers of animals in an experiment were too large to be handled in this time period, the experiment was repeated over 2-3 successive days. 5HTP was always injected intravenously 5,30 or $60 \mathrm{~min}$ before blood sampling. Nialamide $(80 \mathrm{mg} / \mathrm{kg})$ was injected intraperitoneally $20 \mathrm{~h}$ and $2 \mathrm{~h}$ before blood sampling [12]. Benserazide was administered in a dose of $25 \mathrm{mg} / \mathrm{kg}$ intraperitoneally $30 \mathrm{~min}$ before the injection of 5-hydroxytryptophan.

\section{Biochemical Determinations}

Glucose was determined enzymically using a Beckman Glucose Analyzer. Immunoreactive insulin was determined in $50 \mu 1$ plasma samples by the method of Hales and Randle [9] using materials obtained from the Radiochemical Centre (Amersham) and membrane filters (N25/45 UP) purchased from Oxoid. Crystalline rat insulin (Novo Laboratories) was used as a standard. Neither the drugs used nor a major metabolite of 5HT, 5-hydroxyindoleacetic acid (5HIAA) interfered with either determination. The intraassay coefficient of variation was $10.5 \%$ for a nominal $10 \mathrm{mU} / 1$ solution of insulin and $5.2 \%$ for $35 \mathrm{mU} / \mathrm{l}$. The respective interassay coefficients were $39 \%$ and $17 \%$. Comparisons were made only between samples handled in the same assay. The large interassay coefficient of variation may account for some of the variation in fasting insulin levels seen in control animals in this work.

\section{Statistical Methods}

All results were expressed as means \pm SEM. Statistical significance was determined using Student's $t$ test for unpaired data. In the case of IRI, values were found not to follow clearly a normal distribution and therefore $p$ values were estimated using the Mann Whitney U test. Statistical significance was accepted where $\mathrm{P}<0.05$.

\section{Drugs Used}

L-5-hydroxytryptophan, 5-hydroxytryptophan and 5-hydroxyindoleacetic acid were obtained from Sigma. Benserazide was a gift from Roche.

\section{Results}

\section{Effect of 5HTP on Plasma Glucose and IRI} in Normal Mice

In normal fasted mice 5HTP in doses of $50-100 \mathrm{mg} /$ $\mathrm{kg}$ was without effect on plasma glucose. However in larger doses $(200-400 \mathrm{mg} / \mathrm{kg})$ it produced a dose 
Table 2. Effect of pretreatment with benserazide ( $25 \mathrm{mg} / \mathrm{kg} \mathrm{IP,} 30 \mathrm{~min}$ beforehand) on the hypoglycaemic and hyperinsulinaemic effects of L-5-hydroxytryptophan ( $400 \mathrm{mg} / \mathrm{kg} \mathrm{IV)}$. Plasma glucose and IRI were measured 5 and $30 \mathrm{~min}$ after the injection of 5 HTP. Number in parentheses indicates the number of observations. ${ }^{a, b}$ significantly different from control $\left({ }^{a} P<0.01,{ }^{b} P<0.001\right){ }^{c, d}$ significant difference between 5HTP treatments in saline and benserazide pretreated mice $\left({ }^{\mathrm{c}} \mathrm{P}<0.01,{ }^{\mathrm{d}} \mathbf{P}<0.001\right)$

\begin{tabular}{|c|c|c|c|c|c|}
\hline \multirow[t]{2}{*}{ Pre-treatment } & \multirow[t]{2}{*}{ Treatment } & \multicolumn{2}{|c|}{ Plasma glucose, $(\mathrm{mmol} / \mathrm{L})$} & \multicolumn{2}{|c|}{ Plasma IRI, mU/1 } \\
\hline & & $5 \min$ & $30 \mathrm{~min}$ & $5 \min$ & $30 \mathrm{~min}$ \\
\hline Saline IP & Saline IV & $8.2 \pm 0.5(8)$ & $6.3 \pm 0.4(7)$ & $8.1 \pm 0.6(8)$ & $4 \pm 0.8(7)$ \\
\hline Saline IP & 5HTP IV & $8.3 \pm 0.8(8)$ & $2.9 \pm 0.5(7)^{b}$ & $47 \pm 8.8(8)^{\mathbf{a}}$ & $51 \pm 11(7)^{a}$ \\
\hline Benserazide IP & 5HTP IV & $7.3 \pm 0.5(8)$ & $6.5 \pm 0.7(7)^{\mathrm{d}}$ & $9.5 \pm 1.4(8)^{\mathrm{c}}$ & $12 \pm 4(7)^{c}$ \\
\hline
\end{tabular}

dependent hypoglycaemic response when glucose was measured $60 \mathrm{~min}$ after injection (Table 1). Hypoglycaemia was also present 30 min after injection. The plasma IRI concentration was markedly elevated by all doses of 5 HTP at 5 min after injection (Table 1), at which time the plasma glucose concentration was unaltered. The IRI was still raised significantly $30 \mathrm{~min}$ after injection. When blood was collected by simple decapitation without the use of ether, $5 \mathrm{~min}$ after the injection of $5 \mathrm{HTP}(100 \mathrm{mg} / \mathrm{kg}$ IV) or appropriate vehicle, similar insulin values to those presented in Table 1 were obtained (5HTP treated $58 \pm 15 \mathrm{mU} / \mathrm{l}(\mathrm{n}=8)$, control $25 \pm 4 \mathrm{mU} / 1$ $(\mathrm{n}=10), \mathrm{P}<0.05)$. Pre-treatment with benserazide completely prevented the effect of $5 \mathrm{HTP}(400 \mathrm{mg} / \mathrm{kg}$ IV) in elevating the plasma IRI concentration and in producing hypoglycaemia (Table 2).

\section{Effect of Alloxan Diabetes on Response to 5HTP}

Pre-treatment of animals with alloxan markedly changed the responses to 5HTP. In alloxan-diabetic mice $5 \mathrm{HTP}$ in a dose of 100 or $400 \mathrm{mg} / \mathrm{kg}$ produced a marked hyperglycaemic response (Table 1 ).

The response to $400 \mathrm{mg} / \mathrm{kg}$ was however significantly less than the response to $100 \mathrm{mg} / \mathrm{kg}$. Although the plasma insulin concentration was not modified by $5 \mathrm{HTP}$ in a dose of $100 \mathrm{mg} / \mathrm{kg}$ in these mice, there was a small but statistically significant increase in response to the larger dose (Table 1 ).

\section{Effect of 5HTP on Plasma Glucose and IRI in Monoamine Oxidase Inhibitor Treated Mice}

In fasted mice pretreated with nialamide 5HTP $(5 \mathrm{mg} / \mathrm{kg}$ or $10 \mathrm{mg} / \mathrm{kg} \mathrm{IV})$ produced a dose-dependent hypoglycaemia when plasma glucose was estimated at 60 minutes after injection. However plasma insulin concentrations were unaffected by $5 \mathrm{HTP}$ in these mice (Table 3).
Table 3. Effect of various doses of L-5-hydroxytryptophan (5HTP) on the plasma concentration of glucose and immunoreactive insulin (IRI) at 5 and $60 \mathrm{~min}$ after IV administration to mice pretreated with nialamide $(80 \mathrm{mg} / \mathrm{kg} \mathrm{IP}, 20 \mathrm{~h}$ and $2 \mathrm{~h}$ before blood sampling). Each value is the mean \pm SEM of $9-10$ observations.

\begin{tabular}{llllll}
\hline Treatment & \multicolumn{2}{l}{$\begin{array}{l}\text { Plasma glucose } \\
\text { mmol/1 }\end{array}$} & \multicolumn{3}{l}{$\begin{array}{l}\text { Plasma IRI } \\
\mathrm{mU} / 1\end{array}$} \\
\cline { 2 - 3 } \cline { 5 - 6 } \cline { 5 - 6 } & $5 \mathrm{~min}$ & $60 \mathrm{~min}$ & & $5 \mathrm{~min}$ & $60 \mathrm{~min}$ \\
\hline Control & $6.3 \pm 0.4$ & $5.6 \pm 0.2$ & $3 \pm 0.9$ & $4 \pm 1.0$ \\
5 HTP, $5 \mathrm{mg} / \mathrm{kg}$ & $5.7 \pm 0.5$ & $4.8 \pm 0.3^{\mathrm{a}}$ & $4 \pm 1.1$ & - \\
$5 \mathrm{HTP} 10 \mathrm{mg} / \mathrm{kg}$ & $5.2 \pm 0.4$ & $3.2 \pm 0.4^{\mathrm{b}}$ & $5 \pm 1.9$ & $3 \pm 0.8$
\end{tabular}

a,b Indicates that the value is significantly different from the appropriate control ( $\left.{ }^{\mathrm{a}} \mathrm{P}<0.05,{ }^{\mathrm{b}} \mathrm{P}<0.001\right)$

Table 4. Effect of various doses of 5-hydroxytryptamine (5HT) on the plasma glucose concentration of fasted mice and fasted mice pretreated with nialamide $(80 \mathrm{mg} / \mathrm{kg}$ IP $20 \mathrm{~h}$ and $2 \mathrm{~h}$ before blood sampling). Blood samples were removed $60 \mathrm{~min}$ after the injection of $5 \mathrm{HT}$ or control vehicle. The numbers in parentheses indicate the number of observations

\begin{tabular}{lll}
\hline $\begin{array}{l}\text { Doses of } \\
\text { 5HT }(\mathrm{mg} / \mathrm{kg} \mathrm{IV})\end{array}$ & \multicolumn{2}{c}{ Plasma glucose, $\mathrm{mmol} / \mathrm{l}$} \\
\cline { 2 - 3 } & Normal mice & Nialamide-treated mice \\
\hline 0 & $6.8 \pm 0.2$ & $6.4 \pm 0.4$ \\
0.1 & $6.6 \pm 0.3$ & $6.5 \pm 0.6$ \\
1.0 & $7.0 \pm 0.3$ & $6.9 \pm 0.4$ \\
10 & $7.6 \pm 0.4$ & $7.3 \pm 0.5$ \\
50 & $8.3 \pm 0.8$ & $5.9 \pm 0.4$ \\
\hline
\end{tabular}

\section{Effects of $5 H T$ on Plasma Glucose and IRI Concentrations}

$5 \mathrm{HT}(0.1-50 \mathrm{mg} / \mathrm{kg} \mathrm{IV})$ did not modify significantly the plasma glucose concentration in fasted mice or in fasted mice pretreated with nialamide (Table 4). Larger doses could not be studied because of the very 
high mortality produced by doses of $100 \mathrm{mg} / \mathrm{kg}$ and above. In a dose of $50 \mathrm{mg} / \mathrm{kg}$ IV 5 HT produced a small but significant increase in the plasma IRI concentration at $30 \mathrm{~min}$ after injection (Control $6 \pm$ $1 \mathrm{mU} / 1, \mathrm{n}=7 ; 5 \mathrm{HTP}$ treated $22 \pm 3 \mathrm{mU} / 1, \mathrm{n}=8$, $\mathrm{P}<0.001$ ) but not at $5 \mathrm{~min}$.

\section{Discussion}

Previous studies in the mouse have suggested that 5HTP induced hypoglycaemia is not mediated through an increase in insulin secretion. This conclusion was based upon the findings that 5HTP did not elevate the plasma IRI concentration and that the response was still evident in alloxan-diabetic mice [4, 12]. The experiments providing the evidence for these conclusions were all performed using relatively small doses of 5HTP in MAOI pretreated animals. The present findings of hypoglycaemia in response to 5HTP, without hyperinsulinaemia in nialamide treated mice, confirm the previous results. On the other hand we report for the first time the production of hypoglycaemia in response to large doses of 5HTP in animals which have not been treated with an MAOI. Previous studies in such animals have shown either no effect of 5HTP in mice [12] or a hyperglycaemic response in rabbits [16]. However it must be emphasised that these authors used lower doses of 5HTP in fed animals, or animals which had been deprived of food for only a short time.

The observation in the present work that the hypoglycaemia was accompanied by, and, in fact, preceded by a marked increase in the plasma IRI concentration suggests that large doses of 5HTP produce hypoglycaemia by increasing the release of insulin. This interpretation is supported by the prevention or reduction of the hypoglycaemic and hyperinsulinaemic effects of 5HTP by alloxan pretreatment. In alloxan diabetic animals 5HTP actually produced hyperglycaemia. The finding that the hyperglycaemic response to the larger dose of 5HTP was significantly less than the response to a smaller dose may be explained by the finding of a slightly, but significantly, elevated plasma IRI concentration in response to the larger dose. The increase in IRI produced by 5HTP does not appear to result from any chemical interference of 5HTP or its main metabolites with the radioimmunoassay procedure since addition of these substances to solutions of rat insulin did not influence the value determined by assay and, moreover, the increase in IRI was markedly reduced in alloxan diabetic animals. It was possible that the elevation in plasma insulin produced by 5HTP was influenced by the use of ether anaesthesia in the blood sampling procedure. Previous findings from this laboratory have indicated that blood sampling under ether anaesthesia, although not affecting plasma glucose concentrations, influenced markedly the measured concentration of immunoreactive insulin in B. pertussis treated mice [5]. However the hyperinsulinaemic effect of 5HTP was demonstrated readily in animals from which blood was collected by decapitation without the use of anaesthesia.

The present findings in vivo tend to support the in vitro observations of Lernmark [11] and Pontirolli [14] who have shown 5HTP to stimulate the release of insulin from isolated islets of the rat and mouse respectively. On the other hand Wilson et al. [16] showed that the administration of 5HTP to rabbits resulted in an inhibition of glucose-stimulated insulin release from their subsequently incubated pancreatic tissue. Using in vivo experiments in the mouse Lundquist et al. [12] found 5HTP to inhibit the secretion of insulin stimulated by glibenclamide or isoprenaline but not that stimulated by glucose. Although 5HT itself has been shown in several in vitro studies to inhibit insulin release [3, 12] other workers have shown a stimulating effect at low glucose concentrations both in vitro [7] and in vivo [2]. The present work showed 5HT to increase the plasma IRI concentration in the fasted mouse but this was not investigated in sufficient detail to draw comparisons with other work. Moreover 5HT itself did not affect the plasma glucose concentration although doses of $5 \mathrm{HT}$ comparable with those of 5HTP which produced hypoglycaemia could not be administered to the mice. Thus no definite conclusions can be made about the role of $5 \mathrm{HT}$ in mediating the effects of 5HTP. However, the prevention of the responses to 5HTP by benserazide, an inhibitor of aromatic amino acid decarboxylase, suggests strongly that the responses are mediated by some decarboxylated product of 5HTP, and not by the amino acid itself.

Although insulin appears to be involved in the hypoglycaemic action of large doses of 5HTP in normal animals there are several points requiring further discussion. First, it is clear that an increase in the plasma IRI concentration can be produced by $5 \mathrm{HTP}$ in doses lower than those which produce hypoglycaemia, suggesting that other mechanisms may operate to prevent the hyperinsulinaemia from producing a fall in the plasma glucose concentration. That 5HTP exerts actions upon plasma glucose, independently of insulin, tending to produce hyperglycaemia is evident from the experiments in alloxan diabetic mice. Second, the hyperinsulinaemia cannot explain entirely the hypoglycaemic effect of 5HTP since the amino acid produces hypoglycaemia without any change in the plasma IRI concentration in nialamide 
treated mice. Moreover we have shown that various inhibitors of the neuronal uptake of 5HT can augment the hypoglycaemic effect of 5HTP in normal mice without modifying the hyperinsulinaemic effect of 5HTP (Furman and Wilson, unpublished observations; [6]). It thus appears that 5HTP can produce hypoglycaemia in the mouse through at least two different mechanisms. One results in an elevation of the plasma insulin concentration and is seen when large doses of 5HTP are given to normal mice. The second and unknown mechanism is apparently independent of insulin secretion and is seen when 5HTP is given to MAOI pretreated mice or to normal mice treated concurrently with drugs that block the neuronal uptake of 5HTP.

Acknowledgements. We are grateful to the Science Research Council and Organon Laboratories for a CASE award to G. A. W. Additionally we wish to thank Mr. James A. McDonald for his technical assistance.

\section{References}

1. Cegrell L (1968) The occurrence of biogenic monoamines in the mammalian endocrine pancreas. Acta Physiol Scand [Suppl] 314: 1-60

2. Federspil G, Casara D, Pedrazzoli S, Sicolo N, Scandellari C (1974) In vivo studies on 5-hydroxytryptamine and insulin secretion in dogs and in man. Diabetologia 10: 13-17

3. Feldman JM, Lebovitz HE (1970) Serotonin inhibition of in vitro insulin release from golden hamster pancreas. Endocrinology $86: 66-70$

4. Furman BL (1974) The hypoglycaemic effect of 5-hydroxytryptophan. Br J Pharmacol 50: 574-580

5. Furman BL, Wardlaw AC (1979) Influence of the mode of blood sampling on the measured serum level of immunoreactive insulin in Bordetella pertussis treated mice. $\mathrm{Br} \mathrm{J}$ Pharmacol 66: 138
6. Furman BL, Wilson GA (1979) Does the hypoglycaemic effect of 5-hydroxytryptophan involve insulin? $\mathrm{Br} \mathrm{J}$ Pharmacol 67: 488-489

7. Gagliardino JJ, Nierle C, Pfeiffer EF (1974) The effect of serotonin on in vitro insulin secretion and biosynthesis in mice. Diabetologia 10: 411-414

8. Gylfe E, Hellman B, Sehlin J, Taljedal IB (1973) Amino acid conversion into 5-hydroxytryptamine in pancreatic B cells. Endocrinology 93: 932-937

9. Hales CN, Randle PJ (1963) Immunoassay of insulin with insulin-antibody precipitate. Biochem J 33: 137-146

10. Kobayashi B, Ui M, Warashina Y (1960) Role of serotonin in carbohydrate metabolism. I. Glycaemic effect of serotonin in rats. Endocrinol Jpn 7: 225-238

11. Lernmark A (1971) The significance of 5-hydroxytryptamine for insulin secretion in the mouse. Horm Metab Res 3: 305-309

12. Lundquist I, Ekholm R, Ericson LE (1971) Monoamines in the pancreatic islets of the mouse. 5-hydroxytryptamine as an intracellular modifier of insulin secretion and the hypoglycaemic action of monoamine oxidase inhibitors. Diabetologia 7: 414-422

13. McDaniel HG, Boshell BR, Reddy WJ (1973) Hypoglycaemic action of tryptophan. Diabetes 22: 713-718

14. Pontirolli AE, Micossi P, Foa PP (1978) Effects of serotonin, of its biosynthetic precursors and of the anti-serotonin agent metergoline on the release of glucagon and insulin from the rat pancreas. Horm Metab Res 10: 200-203

15. Smith SA, Pogson CI (1977) Tryptophan and the control of plasma glucose concentrations in the rat. Biochem $\mathrm{J}$ 168: 495-506

16. Wilson JP, Downs RW, Feldman JM, Lebovitz HE (1974) B cell monoamines: further evidence for their role in modulating insulin secretion. Am J Physiol 227: 305-312

Received: December 24, 1979 ,

and in revised form: May 16, 1980

B. L. Furman

Department of Physiology and Pharmacology

University of Strathclyde

George Street

Glasgow G1 1XW

Scotland 